\title{
FACTORS INFLUENCING KNOWLEDGE RETENTION PROCESS: CASE OF LITHUANIAN ARMED FORCES
}

\author{
Jurgita RAUDELIŪNIENĖ ${ }^{1 *}$, Vida DAVIDAVIČIENE ${ }^{1}$, Ramūnas PETRUSEVIČIUS² \\ ${ }^{1}$ Department of Business Technologies and Entrepreneurship, Faculty of Business Management, \\ Vilnius Gediminas Technical University, Sauletekio al. 11, LT-10223 Vilnius, Lithuania \\ ${ }^{2}$ Lithuanian Air Force Airspace Surveillance and Control Command, \\ Perlojos g. 93, LT-45312 Kaunas, Lithuania
}

Received 13 November 2016; accepted 18 March 2017

\begin{abstract}
Knowledge management is one of the most potent means for the improvement of Lithuanian armed forces efficiency in context of transformations. Knowledge retention is one of the knowledge management processes that is related to knowledge selection, accumulation of the organization experience, renewal of the organizational memory in order to preserve the valuable knowledge from the potential loss. In order for the Lithuanian armed forces to manage the knowledge effectively and develop - it is important to purposefully preserve the valuable knowledge. The knowledge retention management problems of the Lithuanian armed forces are classified into: human, organizational, functional, technological and technical. In order to solve the problematics of such type, the identification of the factors, that provides the premises for the complex assessment of the knowledge retention process, becomes an important factor. The purpose of the article is to identify the factors that are significant for the evaluation of the knowledge retention process effectiveness of the Lithuanian armed forces. In order to achieve the objective such methods as the analysis of the scientific literature, multiple criteria and expert assessment are employed. According to the research results most factors were attributed to the group of the organizational and knowledge content factors.
\end{abstract}

Keywords: knowledge, knowledge management, knowledge retention, evaluation of knowledge retention process.

JEL Classification: D8, O3, O30.

\section{Introduction}

The constant progress of new technologies, globalization, the appearance of the global markets that ignore the borders of the countries influence not only the changes of the modern society demands, but the competencies of the organizations as well, the latter are utilized in order to satisfy the changing demands of the society and in such way create the value of the organization itself. When assessing the value of the organization and the potential of the

${ }^{\star}$ Corresponding author. E-mail: jurgita.raudeliuniene@vgtu.lt 
owned competencies and resources, the bigger significance is obtained by the knowledge management, it is fulfilled through the procedural model of the knowledge management that comprises the cycle of the processes: knowledge goals, knowledge identification, knowledge acquisition, knowledge development, knowledge sharing and distribution, knowledge application, knowledge retention and knowledge evaluation (Wiig 1993; Meyer, Zack 1996; Probst et al. 2000; Rollet 2003; Raudeliūnienè et al. 2012, 2013, 2016; Kianto et al. 2016).

Lithuanian armed forces can effectively manage the existing knowledge resources only if the knowledge retention process exists. It is important in this process to preserve the valuable knowledge so that organization could effectively utilize, develop it and function.

Lithuanian armed forces often encounter human, organizational, functional, technological and technical problems while trying to effectively preserve and manage the knowledge.

Human problems are being related to the employee forgetfulness, personnel change, staff reduction, retirement, illnesses, loss of valuable employees, it creates preconditions for loss of personal experience.

According to Menon and Pfeffer (2003) the loss of knowledge is related to the inefficiency of motivation and reward systems. According to the scientists each organisation should use the proper motivation and consideration tools in order induce the employees to share the knowledge that is at their disposal with their colleagues and record it. Meta knowledge without which the organisation would have lost its innovation or strategic advantage should not be contained by one individual.

The comprehensive analysis of the problematics of the employee job position reduction commenced even in the eighth decade of the previous century and from then on gets more attention not only from the academic community, but also from the representatives of the public and private sectors, since the reduction of the personnel creates more new challenges that are related to the organization managed knowledge (Habel, Klarmann 2014).

Scientists emphasize that executives of the organizations and their departments should use proper tools, which should ensure uniqueness of the organization after losing the competent personnel. According to the scientists the reduction of the staff in modern organizations is as frequent as the market changes, therefore each organisation should preserve the essential competencies despite the turnover of staff.

According to Luan et al. (2013) if there is a lack of the knowledge retention methods and means, the personnel reduction policy usually is one of the causes for the fall of the organizations (Luan et al. 2013). In this way when leaving the organization the employees took the knowledge that they accumulated during the long years of service causing for the organisation to lose the strong market positions (Martensson 2000; Martins, Meyer 2011; Child et al. 2012). Experienced employees usually are the carriers of the non-expressible knowledge and after they leave the organization, it usually loses a part of the organizational culture or certain properties, knowledge about the management specifics of the operational processes, strategy, products (services). Non-expressible knowledge often has a strategic meaning for the organization because that knowledge is based on the long-term experience of the employees. According to Martins and Meyer (2011) constantly aging experts, who usually possess the strategic knowledge of the organization, when leaving take away the part of the valuable knowledge leaving organization together with them. Therefore, fre- 
quent turnover of the employees, the absence of knowledge retention strategy, the changed point of view of young specialists towards the performed activity, forces many organizations to encounter the lack of the strategic manageable knowledge (Martins, Meyer 2011). Daghfous et al. (2013) distinguishes positive psychological microclimate and motivation, when the employees of the organisation would willingly share the knowledge and after they would leave the organisation that knowledge would remain with the organisation (Daghfous et al. 2013).

The organisational problems occur when selling or reorganising certain structural units of the organisation or disbanding the informal networks when the value of the organizational memory is evaluated insufficiently (Hofer-Alfeis 2008; Lee et al. 2014).

Functional problems related to the purchasing of the external services or when exchanging ordinary functions and procedures for the new ones, when the former essential competencies are lost in the process.

Technological and technical problems form when the organizational memory is erased or lost due to technical malfunctions, absence of the copies, systemic issues, viruses.

In order to solve the problems of such nature and to efficiently manage the knowledge the process of knowledge retention is applied. During the process of the knowledge retention it is important to understand which knowledge should be selected, retained and renewed. The knowledge, personnel competency and the retention of tacit and explicit knowledge that is efficiently managed in the organisation progressively increases the value of the knowledge as of the resource (Zack et al. 2009). As Levy (2011) analyses knowledge retention in the organisations, she states that one of the crucial factors in this area is continuity, i. e. constant work with the available knowledge and the creation of new knowledge on the basis of the available one. If this cycle is interrupted or is disturbed because of any other reasons, the organization incurs losses (Levy 2011).

Therefore the management, evaluation and improvement of the knowledge retention process would provide the premises in the organisation to properly form the strategic decisions for the efficient adaptation in the constantly changing environment by rationally utilising the resources of the organisation and their potential.

The purpose of the article is to identify the factors that are significant in order to evaluate the efficiency of the Lithuanian armed forces knowledge retention process. In order fulfil the objective methods, such as the analysis of the scientific literature, multiple criteria and expert assessment methods are utilised.

\section{Theoretical aspects of the evaluation of the knowledge retention process}

Knowledge retention process has various definitions in the scientific literature (Table 1). When defining the knowledge retention process Choo (1996) emphasizes the time which should be needed to transform the knowledge of experts into the recorded resource of the organization (Choo 1996).

Davenport et al. (1998) emphasize the transformation of the tacit knowledge into the explicit knowledge, so that the former would become accessible to the employees, who are working at the organisation (Davenport et al. 1998). 
Beazley, Boenisch, Harden (2003) associate knowledge retention with the economic foundation of the organization (Beazley et al. 2003).

Madsen et al. (2003) associate the retention of the knowledge in the organization with the fulfilment of the set objectives and the ability to resist the interruptions (Madsen et al. 2003).

According to Subramaniam and Youndt (2005) knowledge retention enables the organization to generate new ideas, social connections and be innovative. According to the latter author new knowledge can be created only on the basis of the current knowledge (Subramaniam, Youndt 2005).

Acsente (2010) states that knowledge should always be separated from the individual in order to prevent the loss of the knowledge when the individual leaves (Acsente 2010).

Shaw and McGregor (2010) emphasize the identification, preservation and the possibilities of use of the meta knowledge that is crucial for the further existence of the organisation (Shaw, McGregor 2010).

Table 1. Definitions of knowledge retention

\begin{tabular}{|l|l|}
\hline \multicolumn{1}{|c|}{ Author (year) } & \\
\hline Choo 1996 & $\begin{array}{l}\text { It is the transformation of the expert knowledge into the resource of the } \\
\text { organization within the shortest time possible. }\end{array}$ \\
\hline Davenport et al. 1998 & $\begin{array}{l}\text { It is the transformation of the individual knowledge into the mutual } \\
\text { knowledge while documenting the latter. }\end{array}$ \\
\hline Beazley et al. 2003 & $\begin{array}{l}\text { It is the transformation of the specific information, knowledge and data } \\
\text { into the basic economic resource within the organization. }\end{array}$ \\
\hline Madsen et al. 2003 & $\begin{array}{l}\text { It is the resistance of the current organizational behaviour against } \\
\text { the inexpedient changes, the seeking of the set objectives despite the } \\
\text { external and internal interruptions. }\end{array}$ \\
\hline $\begin{array}{l}\text { Subramaniam, Youndt } \\
2005\end{array}$ & $\begin{array}{l}\text { It is the creation of the platform within the organization for the } \\
\text { generated ideas, social connections and innovations. }\end{array}$ \\
\hline Shaw, McGregor 2010 & $\begin{array}{l}\text { It is the identification, preservation and utilisation of organization's } \\
\text { crucial knowledge that can be lost. }\end{array}$ \\
\hline Acsente 2010 & $\begin{array}{l}\text { It is the management of human resources in order to ensure that the } \\
\text { knowledge of the separate individuals would remain in the organisation } \\
\text { despite its changes. The knowledge must be separated from the } \\
\text { individual. }\end{array}$ \\
\hline Levy 2011 & $\begin{array}{l}\text { It is the definition; documentation, preservation and integration of the } \\
\text { knowledge that is desired for the preservation back into the operation of } \\
\text { the organization. }\end{array}$ \\
\hline Martins, Meyer 2011 & $\begin{array}{l}\text { It is a regular training and improvement of the personnel in order to } \\
\text { clearly define the roles and responsibilities of the positions within the } \\
\text { activity performed by the organization. }\end{array}$ \\
\hline Carraway 2011 & $\begin{array}{l}\text { It is a process, which allows to identify the problems that had occurred, } \\
\text { what decisions were adopted, what questions should be answered in the } \\
\text { future. }\end{array}$ \\
$\begin{array}{l}\text { It is a process when the employees who possess the knowledge are } \\
\text { solicited, improved or retained, all available IT and other systems are } \\
\text { utilised, so that the knowledge would be retained. }\end{array}$ \\
\hline
\end{tabular}


End of Table 1

\begin{tabular}{|l|l|}
\hline \multicolumn{1}{|c|}{ Author (year) } & \multicolumn{1}{c|}{ Definition } \\
\hline Doan et al. 2012 & $\begin{array}{l}\text { It is the system created in the organization in order to identify, spread, } \\
\text { utilize, influence and increase the managed knowledge and to prevent } \\
\text { the loss of the latter together with the individuals, who leave the } \\
\text { organisation. }\end{array}$ \\
\hline Baporikar 2014 & $\begin{array}{l}\text { It is the basis created in the organization in order to collect, encrypt and } \\
\text { upload the knowledge that is desired for the retention. Knowledge can } \\
\text { be kept in the individuals, who work within the organization and within } \\
\text { the technical media. }\end{array}$ \\
\hline Agrifoglio, Metallo 2015 & $\begin{array}{l}\text { Knowledge retentions it is the main condition for the successful } \\
\text { operation since this process provides the conditions for the individual or } \\
\text { organization to create new knowledge and to improve the current skills. }\end{array}$ \\
\hline
\end{tabular}

Source: created by the Authors.

Levy (2011) emphasizes three components of knowledge retention, without which the process loses its meaning, those include: the definition of knowledge that is desired for the preservation, their documentation and integration into the daily business of the organization (Levy 2011).

When defining the knowledge retention in the organization Sitlington and Marshall (2011) emphasize the constant necessity of the personnel training and the importance of tacitknowledge amongst the personnel. According this scientist, the constant training and improvement is needed so that each member of the organization would precisely knew the limits of his responsibility and duties. According to Sitlington and Marshall (2011) it provides the premises for the organisation to deal with the planned and unplanned personnel turnover problem easier, since if the one employee is replaced the employees who worked with him are aware of his duties and responsibility and make the integration of the latter easier.

When defining knowledge retention process Carraway (2011) compares it to the activity disclaimer. According to this author, it is important to know which problems were encountered, what decisions were adopted and what the result is. Such method of knowledge preservation allows to improve the business procedures, do not repeat the same, usually costly mistakes, as well as predict the future challenges according to the algorithms of the former activity and properly prepare for them (Carraway 2011).

Martins and Meyer (2011) concentrate more at the staff as at the role of the knowledge vessel and when defining the knowledge retention process firstly emphasize the retention of the personnel and only after that the use of all other means for the retention of the personnel knowledge (Martins, Meyer 2011).

According to Martins and Meyer (2011) knowledge retention and loss cannot be considered as antonyms, because the organization will never be able to retain as much knowledge as it is losing, therefore it could be stated that all means that are dedicated for the preservation of the knowledge are warranted and provide benefits. Therefore, organizations must find the efficient methods to retain the knowledge that they possess and prevent the leakage of knowledge when the employees are leaving the organisation. One of the challenges that the organizations are faced with in the context of the knowledge retention is the absence of the 
definition of the knowledge retention process and the absence of the comprehension of its significance (Martins, Meyer 2011).

Doan, Rosenthal-Sabroux, Grundstein (2012) emphasize three processes that are important to the knowledge retention process, those are: identification, preservation and timely distribution. The scientists state that knowledge bank should be constantly updated with new all the time renewed with new experiences and the interest of the organization should be protected in all possible ways in order to curb the joint knowledge and individual migration from the organization (Doan et al. 2012).

Many scientists emphasize that there is a lack of knowledge retention strategy in many organizations, since many executives of the organization focus only on the solutions provided by the information technology when preserving the knowledge while ignoring the importance of human factor (Daghfous et al. 2013). The codification of the available knowledge and too wide utilization of IT shows very limited understanding of the nature of the available knowledge. Intranet, internet, internal databases of the organisations, automated data transfer systems make many of the daily knowledge management processes easier, however only expressible knowledge can be retained in such way. After the individuals, who possess the tacit knowledge, leave such knowledge retention systems can suddenly lose the value (Daghfous et al. 2013).

According to Yeh (2007), Winkelen and McDermott (2008), in order to manage the knowledge retention process effectively, the efficiency of the process must be evaluated comprehensively, starting with the fact that care should be taken after the knowledge retention, presentation and utilisation, starting with the adaptation of the employee hiring (Yeh 2007) until the day of dismissal (Winkelen, McDermott 2008).

According to Larkin and Burgess (2013) if the organization is aiming for the efficient utilization of the knowledge, it should firstly accurately define for itself and understand the knowledge retention process, its benefit for the organization and procedures that would help to accomplish such process successfully (Larkin, Burgess 2013).

Daghfous et al. (2013) state that knowledge retention strategy should include: the audit of the available knowledge, identification of the meta knowledge, timely process of planning, usage possibilities of the modern IT in the knowledge retention processes as well as the sources of their financing and the disclaimer of the standard operating procedures (SOP) (Daghfous et al. 2013).

According to Terzieva (2014) if the organization seeks to properly preserve, apply and create new knowledge, firstly it should answer few questions: what knowledge do we possess and what knowledge do we need; where do the needed knowledge come from; how do we utilize and present the new knowledge; how do we preserve and use the preserved knowledge; who is responsible for the administration of knowledge (Terzieva 2014).

When summarizing the points of view of various scientists, who analyse the definition of the knowledge retention and the importance of the assessment, in order to efficiently perform the work functions and activities, many scientists emphasize the presence of the knowledge preservation strategy in the organization.

Probst, Raub, Romhardt (2000) emphasize the organizational memory as one of the essential factors in the knowledge retention process, it is described as the point of reference of new experiences, because the learning is impossible without the memory. 
Maryam, Denford (Smith, Lyles 2011) distinguish two different types of the organizational memory - internal (knowledge resources that depend on the individuals or groups and their skills in the organization) and external (codified and expressible knowledge of the organization, including formal policy and procedures, documents of various formats). The development of the external organizational memory is related to three main activities: definition of the knowledge content, the identification of the content resources by specifying the means for the collection of the target knowledge; the development of the external memory content by specifying the means of access to the content.

Probst, Raub and Romhardt (2000) distinguish three processes of knowledge retention:

- the selection: from many variables (events, employees, processes) the organization should choose those that are worth of preservation; clearly defined rules and criteria of selection should be set in this process;

- the accumulation: the organization should be capable to accumulate the experience in the proper form, by using the particular employees, groups and IT; the work flow and document management systems create premises to accumulate and retain the valuable knowledge in the electronic memory in this process;

- the renewal: the organization must ensure the renewal of the memory.

- Scientists offer various ways and methods for the preservation of valuable knowledge (Probst et al. 2000; Winkelen, McKenzie 2011):

- the transformation of the expert work into a visible one: when the possibilities to observe the work of experts are provided as they perform certain activities (meetings with experts, mentoring activities, case presentations and discussion with experts, simulation);

- the creation of connection between the expert and the apprentice: manufacturing practices, individual briefing, bilateral teaching;

- the systemic transfer of skills: the teaching of the successors when the tasks are introduced gradually and systemically, and the skills of the master are adopted in this way;

- the principle of the Japanese sempai-kohai: the relationship between two employees in order to create the atmosphere of confidence to share the knowledge, when the senior person (sempai) - teaches and younger (kohai) - is taught;

- the creation of the mutual experience and language: the mutual basic terminology, specific definitions or expressions, the analysis of the situations, those are used by the employees of the organisation to perform the work activity;

- the methods of documentation: knowledge is recorded and preserved in the form of documents (e. g.: minutes);

- the workplace training: the application of training material in work activity;

- the electronic memory: digitized knowledge base where the knowledge assets are systemically accumulated, used and renewed.

The main problem in the knowledge retention process that is encountered by the organizations is the possibility of losing the exceptional employees and the expert knowledge, when they terminate the labour related relationships.

The traditional protection methods of such intellectual capital, such as legal measures, the creation of the favourable work climate, social and economic measures, can be temporary, since the motives of leaving of such experts can be various (for example: the need to create own organization). 
Scientists suggest the possibilities of the various forms of cooperation in order to maintain the experience and connections of the retired experts. For example the former experts can be invited as the consultants to solve the complex problems, to participate in the project activity, conduct seminars, supervise the implementation of projects.

Another suggested alternative is an interview conducted by the specially trained employees with the employee who is terminating the employment agreement. In such way the valuable knowledge is recorded and preserved in the organization.

In order for the organization to efficiently manage the knowledge retention process, it is mandatory to identify the factors that influence the efficiency of the knowledge retention process and their evaluation criteria. The problematics of the knowledge retention process evaluation in the organization has been analysed by many scientists (Davenport et al. 1998; Liebowitz 1999; Stankosky, Baldanza 2000; Chourides et al. 2003; Oliver 2009; Nelson, McCann 2010; Bhuvnender et al. 2012), who suggest to group knowledge retention evaluation factors in various ways.

Massingham (2008) distinguishes four different mediums of knowledge retention in the organization - human, social, structural and interpersonal. Each medium is as valuable for the organization as the quantity of the knowledge that is accumulated it and can be used in the aforementioned field. Human medium is directly related to the efficiency of the personnel management, social - with the culture of the organization, structural - with the knowledge about the organization, consumers and business partners, interpersonal - with the peculiarities of the communication between the people that can significantly differ depending on the culture, religion, ethnic group, status or own experience, etc. (Massingham 2008).

According to B. Meihami and H. Meihami (2014) there are many ways to group the factors that have the biggest influence to the knowledge retention, but there isn't any recipe of success that would fit for several organizations that usually perform very different activities. Before evaluating and grouping knowledge retention factors, every organization must clearly understand the objectives set for the organization itself and the means used for that, since the knowledge is related to the objectives and the means (Meihami, B., Meihami, H. 2014).

According to the Atomic Energy Agency knowledge retention plan, means dedicated to the knowledge preservation in the organization are divided into five groups (McQuade et al. 2007):

- element of the personnel management: involves the recruiting or rotation of new employees, the responsibility development of the current employees and other;

- element of codification and documentation: consists of new and improved procedures, checklists or catalogues, performance motivation models, mutual data bases, intranet, knowledge drivers, photo mediums, conceptual knowledge networks and other;

- element of training and coaching: consists of various trainings, including those in classrooms, also the simulation training computer and video conference training and other; the significance of self-improvement is accentuated, teaching in the place of work and the improvement of qualification by other means, target work tasks, coaching, tutoring, supervision, student-teacher model and other;

- element of process reorganization: consists of process and equipment improvement, smart tools and equipment, assignment of priority to products (or services);

- element of alternative or mutual resources: consists of the knowledge possessed by structural unit experts, rotations, motivation of various skills, parallel assignments, 
additional human resources (hired experts, retired experts who are working part time).

According to Child et al. (2012) the classification of knowledge retention factors should be linkable to the knowledge classification itself. These scientists suggest to classify the factors into personal and group, determining in this way who is the carrier of the knowledge individual or the group of the former. The researchers suggest associating the knowledge retention evaluation factors with the nature of the knowledge - i. e. tacit or explicit knowledge. The significance of the knowledge desired for preservation to the organization is no less important - strategic or tactical knowledge. Child et al. (2012) suggests to evaluate the possibilities of the replacement of the possessed knowledge, after the knowledge carriers are identified there is a necessity to establish whether the knowledge can be replaced after the organization has lost certain employees or data bases (Child et al. 2012).

According to B. Meihami and H. Meihami (2014) when grouping the primary knowledge evaluation factors, the most important thing to know is the objective of the organisation, how to achieve it and what means are used for that ("know-how" and "know-what"). The objective and means to achieve it should regulate the quality, amount and assessment of the knowledge that is being retained (Meihami, B., Meihami, H. 2014).

According to Ruyssen et al. (2012) during the regular meetings the experts in the organization should evaluate several of the knowledge retention process evaluation related aspects: the efficiency and use of employees (individuals, who manage the strategic knowledge in the organization and because for one or other intend to leave their position), means (tools (questionnaires, video records, etc.) that are used for the recording of the knowledge of such employees) and processes for the organization (Ruyssen et al. 2012).

Scientists suggest various methods and ways of the knowledge retention evaluation. One of the most effective ways for the evaluation of the knowledge retention could be the procedures of the constant knowledge auditing. Only during the constant auditing of the knowledge that is being preserved there is a possibility to evaluate what knowledge is lost, how the loss of such knowledge could impact or impacts the business and what should be done in order to prevent the loss of knowledge. Therefore the knowledge retention process and its evaluation should be related to the constant supervision.

According to Hulsebosch et al. (2009) the evaluation takes place at a certain moment and possibly records the change and constant supervision provides the premises to observe a transformation process, its participants, who take place in it and factors that influence the changes. In this way it is possible to determine the causation between the factor and the change. By adapting the knowledge management strategy assessment model of Hulsebosch et al. (2009) and customizing it for the knowledge retention process evaluation, such process could be divided into four components (Hulsebosch et al. 2009).

The first level is the activity that is improving the process of the knowledge retention evaluation, in it are the following aspects that are worth mentioning: target meetings of employees who are responsible for the knowledge retention in organization, creation of the data base, the presentation of the reportable results to the management and employees. At this level it is important to document the scope of the exerted efforts by assessing their efficiency. 
At the second level the current knowledge capital is evaluated, its amount, status, quality. At this level also the achievements of the national and international cooperation in the field of the knowledge accumulation, information accessibility for the ordinary user, and the implementation of innovations are assessed.

At the third level the changes of the working activity are evaluated. How the changes are perceived by separate individuals, groups, teams and structural units. The functionality of changes is also evaluated. When the effective evaluation is being sought - the knowledge capital must have the practical applicability.

At the last level the results of the changes to the activity are evaluated. Usually they should be expressed in numerical value, i. e. profit. The application of such knowledge retention evaluation model provides the possibility to preliminary identify, the level at which the organization should improve its activity in order to manage knowledge retention processes in the most effective way.

Fridell et al. (2011) suggests more comprehensive organizational readiness for change model, the logics of which could be adapted for the evaluation of the knowledge retention process. According to the authors the initial purpose of the model was to evaluate the capability of the organizations that work with the addiction illnesses to apply the innovations, however, later the model was successfully adapted for the evaluations of various processes in various organizations. The essence of the model is comprised of four groups of the evaluation factors: motivation, resources, personal interest of the employees and the climate of the organization (Table 2).

Table 2. Evaluative areas of organizational readiness for change model

\begin{tabular}{|l|l|}
\hline Evaluative area & \multicolumn{1}{c|}{ Evaluative aspects } \\
\hline Motivation & $\begin{array}{l}\text { The need for improvement (whether there is a need in the organization to } \\
\text { clarify the assignments and roles; whether the organization needs to improve } \\
\text { the current knowledge preservation and distribution), the need for training } \\
\text { (whether the personnel at certain positions meets the requirements for the } \\
\text { education), the need for changes (whether there is a need to change the current } \\
\text { procedures of the organization (opinion of the employees, clients and society). }\end{array}$ \\
\hline Resources & $\begin{array}{l}\text { Work premises (whether the offices and work premises provide the possibilities } \\
\text { to reach the objectives of the organization within the context of the evaluated } \\
\text { object); personnel (whether the quantity and quality of the current personnel } \\
\text { provide the premises for the organization to fulfil the objectives); training of } \\
\text { the personnel (whether the training of the personnel is sufficient and whether } \\
\text { is constantly revised); equipment and auxiliary means. }\end{array}$ \\
\hline $\begin{array}{l}\text { Personal interest of } \\
\text { the employees }\end{array}$ & $\begin{array}{l}\text { Career possibilities (whether the knowledge of the evaluated object are directly } \\
\text { related to the career system of the organization); the confidence in own abilities } \\
\text { (whether the requirements for the personnel are reachable); the influence } \\
\text { (whether there is the exchange of the personnel knowledge and evaluation); } \\
\text { the adaptability (whether there are attempts to implement new ideas; whether } \\
\text { the personnel's point of view of new ideas is taken into consideration); job } \\
\text { satisfaction (whether the personnel is satisfied with requirements that are } \\
\text { imposed up them). }\end{array}$ \\
\hline
\end{tabular}




\begin{tabular}{|l|l|}
\hline Evaluative area & \multicolumn{1}{c|}{ Evaluative aspects } \\
\hline $\begin{array}{l}\text { Organizational } \\
\text { climate }\end{array}$ & $\begin{array}{l}\text { Comprehension of assignments (whether the personnel understands their } \\
\text { assignments clearly in the context of the evaluated object and the links of } \\
\text { the organisational objectives); community (whether the personnel is split or } \\
\text { not); autonomy (whether the personnel has a decision - making freedom); } \\
\text { communication; stress (whether the personnel is additionally loaded with } \\
\text { assignments); changes (whether it is easy to implement new work methods in } \\
\text { organization); leadership (whether the personnel trusts the supervisors). }\end{array}$ \\
\hline
\end{tabular}

Source: adopted according to Fridell et al. 2011.

According to Fridell et al. (2011) organizational readiness for change model can be applied for the evaluation of the possibilities of the newly implemented changes and the efficiency of the existing processes (Fridell et al. 2011).

Based on the analysed scientific literature and other sources (legal documents of Lithuania and foreign countries, regulations of Lithuanian armed forces, experience of knowledge retention process evaluation in Lithuanian armed forces and foreign countries), 78 factors that affect the efficiency of the knowledge retention process were distinguished and classified (Table 3).

Table 3. The group classification of the factors that affect the knowledge retention in the organization

\begin{tabular}{|c|c|}
\hline Group & Factors that contribute to knowledge retention in organization \\
\hline Organizational (43) & $\begin{array}{l}\text { Foreign cooperation model (Martins, Meyer 2011; Batista 2014), career system } \\
\text { (Daghfous et al. 2013), usage of common language (Madsen et al. 2003), } \\
\text { workload of workers (Winkelen, McDermott 2008), job roles (Akgun, Keskin } \\
\text { 2012), job action procedures (Levy 2011), bank of organizational competencies } \\
\text { (Batista 2014), summaries of existing documents (IAEA 2006), procedures } \\
\text { (IAEA 2006), document management (IAEA 2006), concept maps (IAEA 2006), } \\
\text { cross functional teams (IAEA 2006), team learning approaches (IAEA 2006), } \\
\text { job rotation model (Hofer-Alfeis 2008), mentoring (Batista 2014), knowledge } \\
\text { workshop (Batista 2014), expert tutorial (Slagter 2009), international practice } \\
\text { (Madsen et al. 2003), reallocation of workforce (Sitlington, Marshall 2011), } \\
\text { Mandatory handover process (Daghfous et al. 2013), acclimatization (Yeh } \\
\text { 2007), program for familiarization with organization (Daghfous et al. 2013), } \\
\text { knowledge elicitation interview (Winkelen, McDermott 2008; Agarwal, Islam } \\
\text { 2015), internal recruitment (Daghfous et al. 2013), replacement (Daghfous et al. } \\
\text { 2013), best practices review (Batista 2014), best practices routinized (Daghfous } \\
\text { et al. 2013), expert assessment (IAEA 2006; Hernandez 2012), knowledge } \\
\text { cafe (Batista 2014), brainstorming (Batista 2014), forums (Batista 2014), } \\
\text { period of time spent in certain positions (Martins, Meyer 2011), workforce } \\
\text { and succession planning (IAEA 2006), standard operating procedures (Clark, } \\
\text { Fujimot 1991), preservation of expert knowledge (Yeh 2007), operation logs/ } \\
\text { event reports (IAEA 2006), identification knowledge at risk (Martins, Meyer } \\
\text { 2011), identification of knowledge carriers (Martins, Meyer 2011), knowledge } \\
\text { sharing (Levy 2011; Daghfous et al. 2013), organizational readiness plan } \\
\text { (Martins, Meyer 2011; IAEA 2006), management of organizational memory } \\
\text { (De Holan et al. 2004; Levy 2011; Sitlington, Marshall 2011), reward system for } \\
\text { knowledge retention within the organization (Batista 2014, IAEA 2006), timely } \\
\text { absorption of new knowledge within the organization (De Holan et al. 2004). }\end{array}$ \\
\hline
\end{tabular}


End of Table 3

\begin{tabular}{|l|l|}
\hline Group & Factors that contribute to knowledge retention in organization \\
\hline $\begin{array}{l}\text { Knowledge content } \\
\text { (11) }\end{array}$ & $\begin{array}{l}\text { Skill framework (Daghfous et al. 2013), simulation training (Landon, Walker } \\
\text { 2009; IAEA 2006), knowledge search tools (Batista 2014), documentation } \\
\text { (Landon, Walker 2009), dismissal interview (IAEA 2006; Daghfous et al. 2013), } \\
\text { buddy strategy (Martins, Meyer 2011), lessons learned (Batista 2014), period } \\
\text { of time spent in international subsidiary (IAEA 2006; Martins, Meyer 2011), } \\
\text { definition of critical knowledge (Levy 2011), knowledge audit (Kamph 2007), } \\
\text { decision summaries (Levy 2011). }\end{array}$ \\
\hline Human (10) & $\begin{array}{l}\text { Bank of organizational competencies (Batista 2014), benchmarking (IAEA } \\
\text { 2006), checklists (Landon, Walker 2009; Levy 2011), coaching (Batista 2014), } \\
\text { collective tacit knowledge (Martins, Meyer 2011), emotional stability (Levy } \\
\text { 2011), involvement in peer communities (IAEA 2006), on the job training } \\
\text { (Landon, Walker 2009), taking responsibility for own learning (Bryson et al. } \\
\text { 2006), time period for renewal of saved data (Martinussen, Hunter 2010). }\end{array}$ \\
\hline Technological (9) & $\begin{array}{l}\text { Computer based training (IAEA 2006), digitization (Ross 2012), electronic } \\
\text { option for saving data (Martins, Meyer 2011), creation of knowledge data base } \\
\text { (Paladino 2007), knowledge saving with computer technology (IAEA 2006), } \\
\text { equipment reliability assessment (IAEA 2006), asset reliability assessment } \\
\text { (IAEA 2006), meta data (IAEA 2006), intranet portals (IAEA 2006). }\end{array}$ \\
\hline Financial (5) \\
$\begin{array}{l}\text { Management of the knowledge data base (IAEA 2006), performance support } \\
\text { systems (Landon, Walker 2009), use of retiring workers (IAEA 2006), efficiency } \\
\text { of money spent for knowledge retention (IAEA 2006), readiness for economic } \\
\text { shocks (Martins, Meyer 2011). }\end{array}$ \\
\hline
\end{tabular}

Source: created by the Authors.

Factors that affect the efficiency of the knowledge retention process were distinguished and classified according substance to the groups of the resources into: human, technological, organizational, knowledge content and financial factor. The evaluation of these 78 factors provide the premises to evaluate the efficiency of the knowledge retention process and to form the suggestions for the improvement.

\section{The evaluation of the knowledge retention process efficiency affecting factors in the Lithuanian armed forces}

\subsection{Research methodology}

Because the knowledge retention process is characterized by the complexity of the evaluation and the variety of factors, for the performance of the research the multiple criteria evaluation methods that belong to the decision adoption group and provide the premises for the complex assessment of the knowledge retention process and adoption of the process improvement related decisions were selected (Zavadskas et al. 1987, 1996, 2008, 2016).

The following sequence of the evaluation of factors affecting the knowledge retention process is suggested (Zavadskas et al. 1987, 1996, 2008, 2016):

- identification of a list of the factors;

- determination of the factors weights and values;

- calculation of a value of the integrated criterion of the evaluation;

- formation of decision-subset and decision-making. 
The integrated criterion $V \nsubseteq$ of factors affecting knowledge retention process is equal to a total of the summation of the values of the initial (of the first stage) and the integrated partial criteria (of the second and the third stage) of factors affecting retention process, $V_{i j}^{k}$, multiplied by their weights (Raudeliūnienè et al. 2012):

$$
V^{\prime}=\sum_{i} \omega_{i} \sum_{j} \omega_{i j} \sum_{k} \omega_{i j}^{k} \cdot V_{i j}^{k},
$$

where $w_{i}$ is the weight of the $i$-th third stage integrated criterion; $w_{i j}$ is the weight of the $j$-th second stage partial integrated criterion; $\omega_{i j}^{k}$ is the weight of the $k$-th first stage initial criterion; $V_{i j}^{k}$ is the value of the initial criterion; $i, j, k$ refer to the indices of the criteria of the particular stages; $i, j, k \in 1,2,3, \ldots, n$, where $n$ stands for the number of the criteria of a particular stage; the total value of the weights of the criteria of each stage is equal to one.

When forming a decision-subset, the largest gap between the maximum possible values of the initial criteria and the measured values of the initial criteria is taken into account (Raudeliūnienè et al. 2012):

$$
A_{i}=\left(N_{i} \cdot \omega_{i j}^{k}\right)-\left(N_{i}^{*} \cdot \omega_{i j}^{k}\right),
$$

where $A_{i}$ is the largest gap between the values of the possible largest and measured initial criteria; $N_{i}$ is the normalized value of the $i$-th initial criterion; $N_{i}^{*}$ is the possible largest normalized value of the $i$-th initial criterion; $\omega_{i j}^{k}$ is the weight of the $i$-th initial criterion of the evaluation.

The proposed method for the evaluation of factors affecting knowledge retention process is characterized by a complex evaluation, and creates preconditions to identify the strengths and weaknesses of knowledge retention process and make decisions based on research results.

In order to identify the factors that affect the knowledge retention process, the expert research was conducted in the December 2015 and January 2016. The officers with the rank of major (OF-3) and higher have been chosen as the experts. In Lithuania the research sample has been determined in accordance with the law on the principle structure of the Lithuanian armed forces in 2016, determination of the planed principle army structure in 2021, and on the approval of the marginal numbers of the defence system soldiers and statutory state officials in 2016 and 2021. The calculated sample of the research was 82 experts (according competence and experience), 61 experts participated in the research, of them: 43 participants from Lithuania and 18 experts from abroad: Estonia (1 expert), Sweden (6 experts), USA (6 experts) and Canada (5 experts).

The professional experience with the army of all experts, who participated in the research is more than 15 years: 38 percent of experts stated that they are working in the army for more than 15 years and 62 percent of experts stated that their professional experience with the army is more than 20 years of service.

90 percent of the experts, who participated in the research had the military rank of OF-3 (major/ commander lieutenant), 8 percent - OF-4 (lieutenant colonel/commander) and 2 percent OF-5 (colonel/sea captain).

It was arranged structured survey for experts in order to qualify list of factors. The experts were requested to rate the significance of the 78 factors that affect the efficiency of the 
knowledge retention process in the scale $[1,4]$, where: 4 - very significant; 3 - significant; 2 - insignificant; 1 - completely insignificant.

International expert survey was organized in such manner that every expert received email letter with a link to electronic survey tool.

\subsection{Results and discussion}

The experts assessed the following factors as the most influential for the efficiency of knowledge retention process: best practices routinized (32 experts, 52 percent, score 3.45), experience assessment (30 experts, 49 percent, score 3.39), knowledge elicitation interviews (18 experts, 30 percent, score 3.29), dismissal interview (9 experts 15 percent, score 3.14), acclimatization (27 experts, 44 percent, score 3.13), programme for the familiarization with organization (23 experts, 38 percent, score 3.04), learned lessons (20 experts, 33 percent, score 2.95), timely absorption of new knowledge within the organization (20 experts, 33 percent, score 2.93), performance support systems (23 experts, 38 percent, score 2.91), knowledge sharing (18 experts, 30 percent, score 2.90) (Fig. 1).

The following factors were evaluated by the experts as significant: knowledge café (17 experts, 28 percent, score 2.88), internal recruitment (12 experts, 20 percent, score 2.85), best practices review (21 experts, 34 percent, score 2.83), workforce or succession planning (15 experts, 25 percent, score 2.78) and brainstorming (13 experts, 21 percent, score 2.77) (Fig. 1).

The least significant factors that influence the knowledge retention efficiency are: bank of organizational competencies (13 experts, 21 percent, score 2.37), time period spent in different positions ( 8 experts, 13 percent, score 2.36), bank of individual competencies (10 experts, 16 percent, score 2.34), job rotation model ( 9 experts, 15 percent, score 2.34 ), decision summaries ( 9 experts, 15 percent, score 2.32), knowledge search tools ( 6 experts, 10 percent, score 2.27), concept maps ( 8 experts, 13 percent, score 2.27 ), use of retiring/retired workers (8 experts, 13 percent, score 2.27), knowledge audit (6 experts, 10 percent, score 2.21), effectiveness of money spent on the knowledge retention (6 experts, 10 percent, score 2.01) (Fig. 1).

Data collected during this research allows to presume that knowledge preservation in the organization is directly related to the implementation of good practice in the daily activity and constant experience evaluation. Knowledge elicitation and dismissal interviews also received high evaluations, during them the experience and knowledge possessed by the separate individuals can be documented, assessed and later integrated in the daily activity of the organization. The experts gave high marks for the acclimatization, programs for familiarization with the organization, timely absorption of new knowledge within the organization and the knowledge sharing.

The experts were asked to group the factors that affect the efficiency of knowledge retention process according the content into following groups: human, financial, organizational, technological, knowledge content. According to the expert assessment the most factors were assigned to the group of organizational factors (43 factors, 55 percent), knowledge content (11 factors, 14 percent.), human (10 factors, 13 percent), technological ( 9 factors, 12 percent) and the least were assigned to the financial factor group (5 factors, 6 percent) (Table 4 ). 


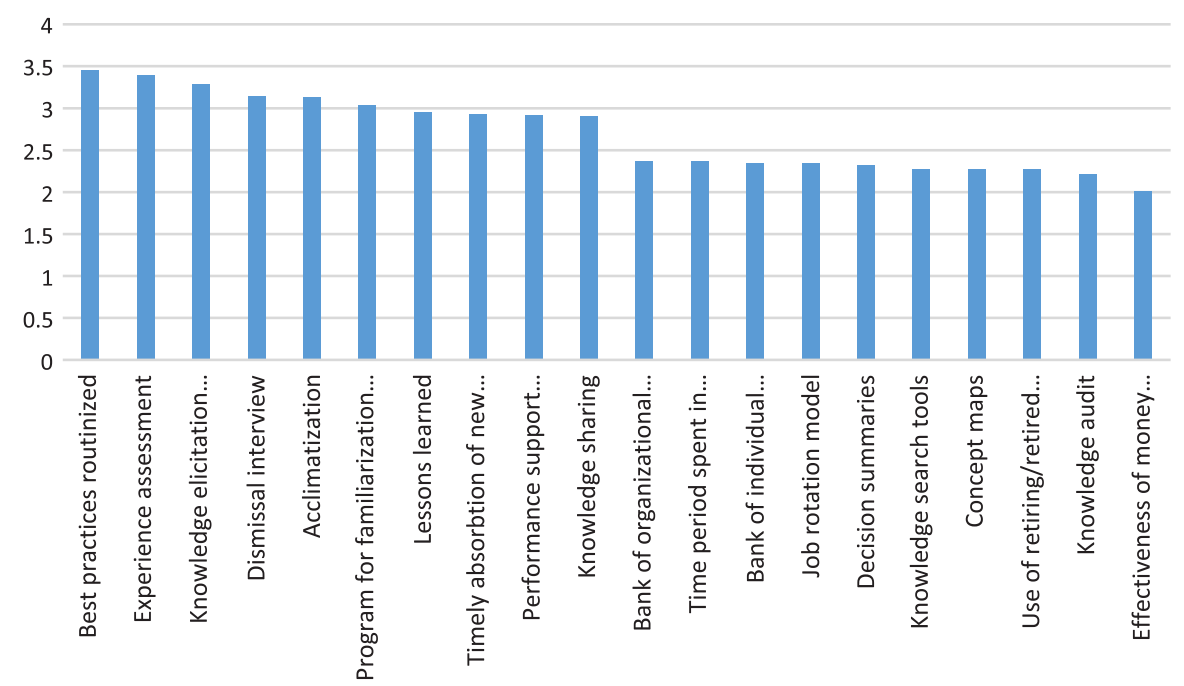

Source: created by the Authors.

Fig. 1. The importance of different factors for the knowledge retention in the Lithuanian armed forces

Table 4. Group classification of the most important factors

\begin{tabular}{|c|c|}
\hline $\begin{array}{l}\text { Group (number of } \\
\text { factors) }\end{array}$ & Factors and their ratings (percent) \\
\hline Organizational (43) & 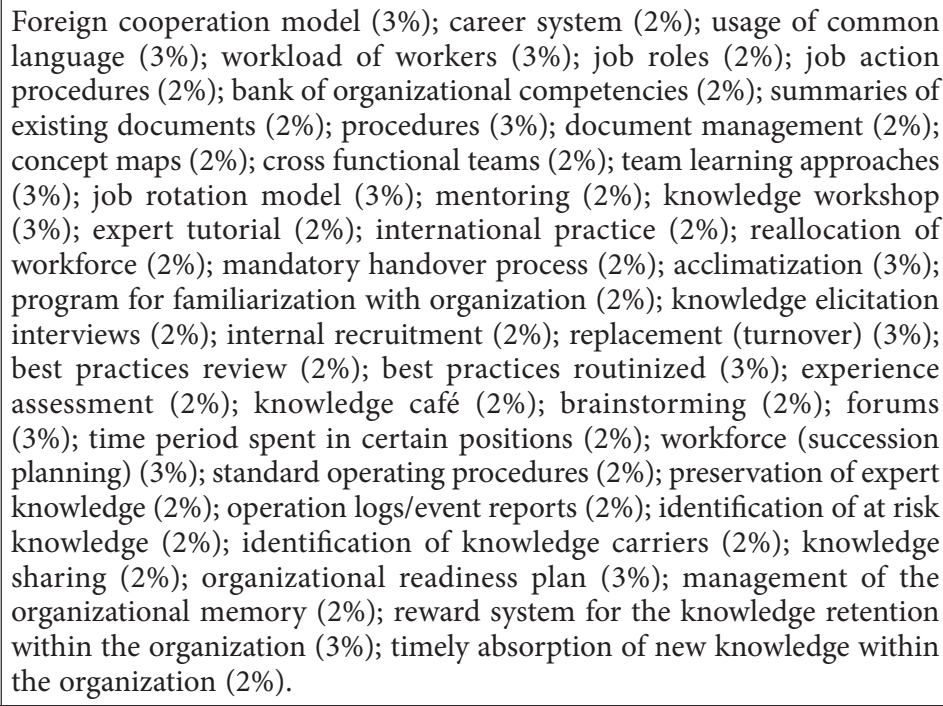 \\
\hline Knowledge content (11) & $\begin{array}{l}\text { Skill frameworks (9\%); simulation training (10\%); knowledge search tools } \\
(8 \%) \text {; documentation (8\%); dismissal interview (9\%); buddy strategy (8\%); } \\
\text { learned lessons (8\%); period of time spent in the international subsidiary } \\
\text { (10\%); definition of the critical knowledge (11\%); knowledge audit (8\%); } \\
\text { decision summaries (11\%). }\end{array}$ \\
\hline
\end{tabular}


End of Table 4

\begin{tabular}{|l|l|}
\hline \multicolumn{1}{|c|}{$\begin{array}{c}\text { Group (number of } \\
\text { factors) }\end{array}$} & \multicolumn{1}{|c|}{ Factors and their ratings (percent) } \\
\hline Human (10) & $\begin{array}{l}\text { Taking responsibility for own learning (12\%); involvement in peer } \\
\text { communities (9\%); benchmarking (15\%); collective tacit knowledge (9\%); } \\
\text { emotional stability (10\%); bank of individual competencies (9\%); time } \\
\text { period for renewal of saved data (9\%); on the job training (OJT) (10\%); } \\
\text { coaching (8\%); checklists (9\%). }\end{array}$ \\
\hline Technological (9) & $\begin{array}{l}\text { Computer based training (13\%); digitization (10\%); electronic options } \\
\text { for saving knowledge (13\%); creation of knowledge database (10\%); } \\
\text { knowledge saving with the computer technology (12\%); equipment } \\
\text { reliability assessment (10\%); asset reliability assessment (9\%); intranet } \\
\text { portals (11\%); meta data (12\%). }\end{array}$ \\
\hline Financial (5) & $\begin{array}{l}\text { Management of knowledge data base (20\%); performance support systems } \\
\text { (19\%); use of retiring/retired workers (17\%); efficiency of money spent } \\
\text { for knowledge retention (25\%); readiness for the economic shocks (19\%). }\end{array}$ \\
\hline
\end{tabular}

Source: created by the Authors.

According to the expert assessment the knowledge preservation in the organization mostly depends on the organizational factors (55 percent) for the implementation of which the organisation itself is responsible, it is less dependent on the knowledge content (14 percent), human (13 percent), technological (12 percent) factors, and least of all on the group of the financial (6 percent) factors.

\section{Conclusions}

Knowledge possessed by the organization and its preservation is one of the essential processes of the knowledge management. This intangible resource that is constantly accumulated and properly managed by the organization allows it to create the uniqueness that is hard to copy by other organizations.

Aspects of the knowledge retention in the organization have been analysed by many scientists, who emphasized that knowledge preservation in the organization is a complex and sophisticated phenomenon that probably has the most influence to the originality of the organization. The scientists who analyse the problematics of the knowledge retention in the organization emphasize that only a part of knowledge capital managed by the organisation can be in explicit form, the other part remains in tacit form. Currently the individual is the vault of knowledge. Such distribution of knowledge managed by the organization and high turnover of personnel can negatively impact the intangible assets (knowledge) managed by the organization. It lets to assume, that in order to maintain the successful life cycle of the organization, the interaction between tacit and explicit knowledge is needed, therefore the proper identification, encryption and preservation of the latter can have the strategic meaning for the further existence and development of the organisation.

In order to solve this problem the factors that affect the efficiency of the knowledge retention process have been identified by utilising the expert and multiple criteria evaluation methods. The list of the evaluation factors of the primary knowledge retention in the 
organisation was comprised of 78 factors that were grouped according to their content into five groups: organizational, knowledge content, human, technological and financial.

In order to identify the knowledge retention process influencing factors that are the most important for the military organization the expert evaluation was performed. Officers with the military rank no lower than major (OF-3) were selected as experts. In total 61 experts from Lithuania, USA, Canada, Sweden and Estonia took part in the international expert survey.

During the research it was established that the most significant knowledge retention evaluation factors in military organization are: routinized best practices, experience assessment, knowledge elicitation interviews, dismissal interview, acclimatization, familiarization with organization program, etc. The least significant knowledge retention evaluation factors in military organization are: bank of the organizational competencies, time period spent in different positions, the job rotation model, etc.

According to the expert assessment most factors were attributed to the group of the organizational factors (43 factors, 55 percent), knowledge content (11 factors, 14 percent), human (10 factors, 13 percent), technological ( 9 factors, 12 percent) and the least number was attributed to the financial (5 factors, 6 percent) factors.

In order to preserve the knowledge in the military organization more attention should be paid to: the implementation of the good practice in the daily activity (best practices routinized, lessons learned), expert evaluations (experience assessment), the interviews with the employees during which the tacit knowledge is transformed into the explicit (knowledge elicitation interviews, dismissal interview), the targeted introduction of new employees into the organizational activity (acclimatization, program for familiarization with organization), the active and timely search and implementation of innovations in the organization (timely absorption of new knowledge within organization), the creation, maintenance and active use of the employee motivation and promotion systems (performance support systems), constant and timely assurance of the knowledge sharing process amongst the employees that are acting within the organization.

The future research would be related with determination of the knowledge retention process factors values, calculation of a value of the integrated criterion of the evaluation, formation of decision-subset and decision-making, that provides the premises for the complex assessment of the knowledge retention process and for improvement of process.

\section{References}

Agarwal, N. K.; Islam, Md. A. 2015. Knowledge retention and transfer: how libraries manage employees leaving and joining, VINE 45(2): 150-171. https://doi.org/10.1108/VINE-06-2014-0042

Agrifoglio, R.; Metallo, C. 2015. Preserving knowledge through community of practice: a multiple case study, From Information to Smart Society 5: 103-111.

Akgun, A. E.; Keskin, H. 2012. Organizational emotional memory, Management Decision 50(1): 95-114. https://doi.org/10.1108/00251741211194895

Acsente, D. 2010. Literature review: a representation of how future knowledge worker is shaping the twenty - first century workplace, On the Horizon 18(3): 279-287.

https://doi.org/10.1108/10748121011072726 
Baporikar, N. 2014. Knowledge management in public sector organizations: a strategic approach, An International Journal of Management Studies 4(4): 1-6.

Batista, F. F. 2014. Knowledge management in public administration: Brasil versus Portugal, in Proceedings of the $15^{\text {th }}$ European Conference on Knowledge management. Polytechnic Institute of Santarem, Portugal, 4-5 September, 82-95.

Beazley, H.; Boenisch, J.; Harden, D. 2003. Knowledge continuity: the new management function, Journal of Organizational Excellence 22(3): 65-81. https://doi.org/10.1002/npr.10080

Bhuvnender, C.; Saurabh, T.; Nidhi, S. 2012. Recruitment \& retention of knowledge worker in an organization, Asia Pacific Journal of Research in Business Management 3(1): 1-4.

Bryson, J.; Pajo, K.; Ward, R.; Mallon, M. 2006. Learning at work: organizational affordances and individual engagement, Journal of Workforce Learning 18(5): 279-297. https://doi.org/10.1108/13665620610674962

Carraway, L. N. 2011. On preserving knowledge, The American Midland Naturalist 166(1): 1-12. https://doi.org/10.1674/0003-0031-166.1.1

Child, J.; Duarte, R. G.; Tanure, B.; Rodrigues, S. B. 2012. Access to tacit knowledge by executive retention in cross-border acquisitions, Brazilian Administration Review 9(3): 329-350. https://doi.org/10.1590/S1807-76922012000300006

Choo, C. W. 1996. The knowing organization: how organizations use information to construct meaning, create knowledge and make decisions, International Journal of Information Management 16(5): 329-340. https://doi.org/10.1016/0268-4012(96)00020-5

Chourides, P.; Longbottom, D.; Murphy, W. 2003. Excellence in knowledge management: an empirical study to identify critical factors and performance measures, Measuring Business Excellence 7(2): 29-45. https://doi.org/10.1108/13683040310477977

Clark, K.; Fujimot, T. 1991. Product development performance. Harvard business school press, Boston, MA.

Daghfous, A.; Belkhodja, O.; Angell, L. C. 2013. Understanding and managing knowledge loss, Journal of Knowledge Management 17(5): 639-660. https://doi.org/10.1108/JKM-12-2012-0394

Davenport, T. H.; De Long, D. W.; Beers, M. C. 1998. Successful knowledge management projects, Sloan Management Review 39: 39-46.

De Holan, P. M.; Phillips, N.; Lawrence T. B. 2004. Managing organizational forgetting, MIT Sloan Management review 45(2): 44-51.

Doan, Q. M.; Rosenthal-Sabroux, C.; Grundstein, M. 2012. A reference model for knowledge retention within small and medium-sized enterprises, 1-7 [online], [cited 04 September 2016]. Available from Internet: http://www.lamsade.dauphine.fr/scripts/FILES/publi1700.pdf

Fridell, M.; Holmberg, R.; Billsten, J.; Benderix, Y. 2011. Utvärdering av kunskap till praktik. Ett nationellt stöd till implementering av Nationella riktlinjer för missbruks och beroende vården. Lunds och Linne universitet. 189 p. (in Swedish).

Habel, J.; Klarmann, M. 2014. Customer reactions to downsizing: when and how is satisfaction affected?, Journal of Academy of Marketing Science 1-22.

Hernandez, D. H. 2012. The dangerous gap between American society and its military [online], [cited 04 September 2016]. Army war colledge, Carlisle Barracks, PA. Available from Internet: https:// www. dtic.mil/cgi-bin/GetTRDoc?AD=ADA561203

Hofer-Alfeis, J. 2008. Knowledge management solutions for leaving expert issue, Journal of Knowledge Management 12(4): 44-54. https://doi.org/10.1108/13673270810884246

Hulsebosch, J.; Turpin, M.; Wagenaar, S. 2009. Monitoring and evaluating knowledge management Strategies. IKM Background Paper series. $44 \mathrm{p}$. 
IAEA (International Atomic Energy Agency). 2006. Knowledge management for nuclear industry operating organizations. Information prepared by: International Nuclear Information System and Nuclear Knowledge Management section. Wagramer Strasse 5, Vienna, Austria.

Kamph, B. 2007. A bottom line approach to knowledge retention, Power Engineering 111(4): 92.

Kianto, A.; Vanhala, M.; Heilmann, P. 2016. The impact of knowledge management on job satisfaction, Journal of Knowledge Management 20(4): 621-636. https://doi.org/10.1108/JKM-10-2015-0398

Landon, A.; Walker, B. 2009. Knowledge retention: preventing knowledge from walking out the door, An overview of processes and tools at the Tenessee Valey Authority [online], [cited 16 July 2016]. Available from Internet: http://tva.gov/ knowledgeretention

Larkin, R.; Burgess, J. 2013. The paradox of employee retention knowledge transfer, Employment Relations Record 13(2): 32-43.

Lee, T. W.; Burch, T. C.; Mitchell, T. R. 2014. The story of why we stay: a review of job embeddedness, Annual Review of Organizational Psychology and Organizational Behavior 1: 199-216. https://doi.org/10.1146/annurev-orgpsych-031413-091244

Levy, M. 2011. Knowledge retention: minimizing organizational business loss, Journal of Knowledge Management 15(4): 582-600. https://doi.org/10.1108/13673271111151974

Liebowitz, J. 1999. Key ingriedients to the success of an organization's knowledge management strategy, Knowledge and Process Management 6(1): 37-40. https://doi.org/10.1002/(SICI)1099-1441(199903)6:1<37::AID-KPM40>3.0.CO;2-M

Luan, C. J.; Tien, C.; Chi, Y. C. 2013. Downsizing to the wrong size? A study of the impact of downsizing on firm performance during an economic downturn, The International Journal of Human Resource Management 24: 1519-1535. https://doi.org/10.1080/09585192.2012.725073

Madsen, T. L.; Mosakovski, E.; Zaheer, S. 2003. Knowledge retention and personnel mobility: the nondisruptive effects of inflows of experience, Organization Science 14(2): 173-191. https://doi.org/10.1287/orsc.14.2.173.14997

Martensson, M. 2000. A critical review of knowledge management as a management tool, Journal of Knowledge Management 4(3): 204-216. https://doi.org/10.1108/13673270010350002

Martins, C. E.; Meyer, H. W. J. 2011. Organizational and behavioral factors that influence knowledge retention, Journal of Knowledge Management 16(1): 77-96. https://doi.org/10.1108/13673271211198954

Martinussen, M.; Hunter, D. R. 2010. Aviation psychology and human factors. Boca Raton, FL. CRC Press.

Massingham, P. 2008. Measuring the impact of knowledge loss: more than ripples on a pond?, Management Learning 39(5): 541-560. https://doi.org/10.1177/1350507608096040

McQuade, E.; Sjoer, E.; Fabian, P.; Nascimento, J. C.; Schroeder, S. 2007. Will you miss me when I'm gone? A study of the potential loss of company knowledge and expertise as employees retire, Journal of European Industrial Training 31(9): 758-768. https://doi.org/10.1108/03090590710846701

Meihami, B.; Meihami, H. 2014. Knowledge management a way to gain a competitive advantage in firms (ecidence of manufacturing companies), International Letters of Social and Humanistic Sciences 3: 80-91.

Menon, T.; Pfeffer, J. 2003. Valuing internal versus external knowledge, Management Science 49(3): 497-513. https://doi.org/10.1287/mnsc.49.4.497.14422

Meyer, M.; Zack, M. 1996. The design and implementation of information products, Sloan Management Review 37(3): 43-59.

Nelson, K.; McCann, J. E. 2010. Designing for knowledge worker retention \& organization performance, Journal of Management and Marketing Research 1: 1-18. 
Oliver, J. 2009. Continuous improvement: role of organizational learning mechanisms, International Journal of Quality and Reliability Management 26(6): 546-563. https://doi.org/10.1108/02656710910966129

Paladino, B. 2007. Five key principles of corporate performance management. New Jersey. John Wiley \& Sons. $402 \mathrm{p}$.

Probst, G. J. B.; Raub, S.; Romhardt, K. 2000. Managing knowledge: building blocks for success. Wiley. $368 \mathrm{p}$.

Raudeliūnienè, J.; Meidute, I.; Martinaitis, G. 2012. Evaluation system for factors affecting creativity in the Lithuanian Armed Forces, Journal of Business Economics and Management 13(1): 148-166. https://doi.org/10.3846/16111699.2011.639797

Raudeliūnienė, J.; Tunčikiene, Ž.; Petrusevičius R. 2013. Competency assessment of professional military service in Lithuanian armed forces, Journal of Security and Sustainability Issues 3(1): 61-71. https://doi.org/10.9770/jssi.2013.3.1(7)

Raudeliūnienè, J.; Meidutè-Kavaliauskienè, I.; Vileikis, K. 2016. Evaluation of factors determining the efficiency of knowledge sharing process, Journal of the Knowledge Economy 7(4): 842-857. https://doi.org/10.1007/s13132-015-0257-4

Rollet, H. 2003. Knowledge management: processes and technologies. Boston: Kluwer Academic Publishers. 231 p. https://doi.org/10.1007/978-1-4615-0345-3

Ross, S. 2012. Digital preservation, archival science ad methodological foundations for digital libraries, New Review of Information Networking 17(1): 43-68. https://doi.org/10.1080/13614576.2012.679446

Ruyssen, M. L.; Moons, F.; Borgemans, P. 2012. Managing nuclear knowledge: A SCK CEN concerns: status of practical knowledge management approach, IAEA-CN-123/02/P/02 1-8.

Shaw, D.; McGregor, G. 2010. Making memories available: a framework for preserving rural heritage through community knowledge management, Knowledge Management Research and Practice 8: 121-134. https://doi.org/10.1057/kmrp.2010.7

Sitlington, H.; Marshall, V. 2011. Do downsizing decisions affect organizational knowledge and performance?, Management Decision 49(1): 116-129. https://doi.org/10.1108/00251741111094473

Slagter, F. 2009. HR practices as predictors for knowledge sharing and innovative behavior: a focus on age, International Journal of Human Resources Development Management 9(2/3): 223-249. https://doi.org/10.1504/IJHRDM.2009.023454

Smith, M. E.; Lyles, M. A. 2011. Handbook of organizational learning and knowledge management. 2nd ed. John Wiley \& Sons Ltd, United Kingdom. 711 p.

Stankosky, M. A.; Baldanza, C. 2000. Knowledge management: an evolutionary architecture toward enterprise engineering. International Council on System Engineering (INCOSE), Reston, VA.

Subramaniam, M.; Youndt, M. A. 2005. The influence of intellectual capital on the types of innovative capabilities, Academy of Management Journal 48(3): 450-463. https://doi.org/10.5465/AMJ.2005.17407911

Terzieva, M. 2014. Project Knowledge management: how organizations learn from experience, Procedia Technology 16: 1086-1095. https://doi.org/10.1016/j.protcy.2014.10.123

Wiig, K. M. 1993. Knowledge management foundations - thinking about thinking - how people and organizations create, represent and use knowledge. Arlington, TX: Schema Press. 428 p.

Winkelen, C.; McDermott, R. 2008. Facilitating the handover of knowledge, Knowledge Management Review 11(2): 24-27.

Winkelen, C.; McKenzie, J. 2011. Knowledge works: the handbook of practical ways to identify and solve common organizational problems for better performance. John Willey \& Sons Ltd, United Kingdom. $311 \mathrm{p}$. 
1124 J. Raudeliüniene et al. Factors influencing knowledge retention process: case of Lithuanian armed forces

Yeh, Y. M. C. 2007. A renewed look at the turnover model for accounting knowledge work force, Journal of The American Academy of Business 11(1): 103-109.

Zack, M.; Mckeen, J.; Singh, S. 2009. Knowledge management and organizational performance: an exploratory survey, Journal of Knowledge Management 13(6): 392-409. https://doi.org/10.1108/13673270910997088

Zavadskas, E. K. 1987. Kompleksnaya otsenka i vybor resursosberegayushchikh resheniy $v$ stroitel'stve [Complex estimation and choice of resource saving decisions in construction]. Vilnius: Mokslas (in Russian).

Zavadskas, E. K.; Kaklauskas, A. 1996. Pastatu sistemos techninis įvertinimas [Building Systems Technical Assessment]. Vilnius: Technika. 280 p. (in Lithuanian).

Zavadskas, E. K.; Turskis, Z.; Tamošaitienė, J.; Marina, V. 2008. Multicriteria selection of project managers by applying grey criteria, Technological and Economic Development of Economy 14(4): 462-477. https://doi.org/10.3846/1392-8619.2008.14.462-477

Zavadskas, E. K.; Mardani, A.; Turskis, Z.; Jusoh, A.; Nor MD, K. 2016. Development of TOPSIS method to solve complicated decision-making problems - an overview on developments from 2000 to 2015, International Journal of Information Technology \& Decision Making 15(3): 645-682. https://doi.org/10.1142/S0219622016300019

Zavadskas, E. K. 1987. Kompleksnaya otsenka i vybor resursosberegayushchikh resheniy $v$ stroitel'stve [Complex estimation and choice of resource saving decisions in construction]. Vilnius: Mokslas (in Russian). 